Postdoc

Institut for Kunst- og Kulturvidenskaber, Københavns Universitet

\title{
UTOPISK SLÆGTSKAB I UDRYDDELSENS TID
}

Bare leve og forplante sig

Leve og forplante sig

Formere sig, dø, vende tilbage til livet og formere sig igen.

- Hiromi Ito

Refrænet "bare leve og forplante sig" i den japanske digter Hiromi Itos digtsamling Vildgræs ved flodlejet fra 2005 kan virke provokerende naivt i betragtning af, at menneskelig formering aldrig "bare" finder sted uden for de politiske og sociale konfigurationer, der gør det muligt at skabe og vedligeholde liv. Og hyldesten til naturens livscyklus er ligeledes svær at synge med på, når vi ved, at plante- og dyrearter uddør med en uset hastighed i menneskehedens historie og med konsekvenser, som vil ramme mennesker overalt på jorden. ${ }^{1}$ Men Itos digtning kredser om slægtskab og

1 IPBES-rapporten fra FN's biodiversitetspanel konkluderede i maj 2019, at naturgrundlaget ødelægges med enorm hastighed, og at den globale handel, som er tidoblet gennem de seneste 50 år, har konsekvenser for biodiversiteten og bør ændres tillige med radikale omstillinger i alle dele af samfundet. Resuméer af rapporten findes her: https://www.ipbes.net/sites/default/files/downloads/spm_unedited_advance_for_posting_htn.pdf(Web, 25. marts 2020) og her: https://www.un.org/sustainabledevelopment/blog/2019/05/nature-decline-unprecedented-report/(Web, 25. marts 2020). 
40 KULTUR \& KLASSE $* 129 * 2020$

KLIMA, MAGT, MODSTAND
41 IBEN ENGELHARDT ANDERSEN

UTOPISK SL ÆGTSKAB I UDRYDDELSENS TID økologi på måder, der tilbagelader enhver idyllisering af naturens processer. Hvor der er menneskebabyer, er der også blod og lort, og hvor der er cirkularitet, er der også gentagelse og undertrykkelse. Itos digtning kan betragtes som forsøg på at give sprog til en kosmologisk sammenhæng, hvor mennesket står side om side med alt andet, hvor alle arter gælder. Men relationerne med naturen foranlediger også et vedholdende ubehag - opkast, diarré, udslæt og sex overtager sproget i digtene, der ubønhørligt forbinder reproduktion og død.

Spørgsmål om reproduktion knytter sig til den økologiske katastrofe på flere niveauer: Det handler i første omgang om den biologiske formering på det individuelle plan - skal jeg lave flere børn, der arver de økologiske, sociale og somatiske konsekvenser af mine og mine umiddelbare forfædres uansvarlige levevis? Skal jeg lave børn, der i hvert fald i denne del af verden vil bidrage til nedslidningen af de fælles ressourcer, som allerede pågår? Disse spørgsmål bliver hurtigt til kollektive spørgsmål: Hvilke implikationer har reproduktionen af den gældende orden? Hvordan er den biologiske og den sociale reproduktion forbundne i historiske, sociale og kulturelt specifikke kontekster? Og hvad er (mis)forholdet mellem barndommen som en ophøjet symbolik og de faktiske forhold som det reproduktive arbejde - fødsel, børnepasning, rengøring, omsorg m.m. - udføres under?

Barnet er en påmindelse om menneskets forbindelser til naturen og fungerer samtidig som en garant for menneskelivets transit ind i fremtiden. Dette er min påstand om barnets plads i det kollektive imaginære, mens det samtidig tydeliggør, hvordan biologi, sociale praksisser og fantasmer påvirker hinanden. Det er svært at skelne mellem barnet som natur, som fremtidsfigur og som konkret arvtager af den verden, vi har skabt. Den økologiske tanke bringer i høj grad disse niveauer sammen, ligesom den forbinder intime spørgsmål og globale problematikker.

Hvilken rolle spiller barnet og reproduktionen for, hvordan vi forestiller os fremtiden i en tid, hvor den industrielle produktion på den ene side har ført til en udmattelse af liv: masseuddøen, sterilitet, udpining og udtørring, og på den anden side har skabt en katastrofisk vitalitet: jordskælv, orkaner, oversvømmelser, der trodser alle fantasier om naturens medgørlighed? Mens der findes en utopisk impuls i Itos poetiske hårdførhed, hvor undergangen bærer på en vis håbefuldhed, undersøger jeg i denne artikel, hvad den uto- piske tankes muligheder og fremtrædelsesformer er i en samtid, hvor økokatastrofen har bragt den håbefulde og udskudte fremtidshorisont i krise.

Jeg præsenterer tre utopiske perspektiver på forviklingerne og forpligtelserne mellem reproduktion og økologisk bæredygtighed. I første omgang skal det handle om Inger Christensens beskrivelser af fødsel, energi og arbejde i hendes tekster om utopien fra 1970'erne. Christensens naturtænkning, hvor mennesket snarere end at være behersker og beskytter af naturen, er en del af den, virker relevant nu, hvor menneskets indlejring i naturen bliver mere og mere tydelig for flere og flere af os. Samtidig forbinder Christensen et cirkulært natursyn med en utopisk impuls, hvilket udfordrer ideen om utopien som en helt ny begyndelse. Dernæst skal det handle om det, jeg kalder "ikke-reproduktion". Mens Donna Haraway i sin seneste bog Staying with the Trouble forsøger at tænke slægtskab på nye måder som noget, der involverer flere arter og opgør med en heteroseksuel to-forældre-norm, er der også uomgængeligt fascistiske implikationer af at svare på klimakrisen ved at ønske sig færre mennesker på jorden. Sidst laver jeg en kort læsning af Hiromi Itos seneste digtsamling Vildgræs ved flodlejet som en tvetydig utopi. Dels fremhæver den de grænsedragninger, som også må adresseres i spørgsmålet om økokrisens fremtidstab. Dels præsenterer den et radikalt slægtskab barn og plante imellem. Disse tre perspektiver - cirkulær energi, ikke-reproduktion og radikalt slægtskab - er også mulige diskussioner med det, Lee Edelman berømt har kaldt reproduktiv futurisme, som er en politisk forestillingshorisont, der sætter lighedstegn mellem heteroseksuel reproduktion og social reproduktion.

Derfor vil jeg først kort skitsere Edelmans queer "nej" til den reproduktive futurisme. Han står for en anti-utopisk radikalitet, en nægtelse af overhovedet at tænke i fremtidige termer. Men Edelmans diagnose udfordres af en generel krise i den politiske imagination af fremtiden, og hans kritik kan suppleres ved at tænke queer, utopi, reproduktion og økologi sammen.

\section{ANTI-UTOPI}

Mens queer epistemologisk er forbundet med uforståelighed, antiproduktion og nonsens, beskriver den reproduktive futurisme en politisk fremtid, som betyder mere af det samme, og hvor barnet er garant for denne 
43 IBEN ENGELHARDT ANDERSEN

UTOPISK SLÆGTSKAB I UDRYDDELSENS TID ensartethed. Det er det uskyldige barn, der skal bevares og beskyttes, for at verden kan fortsætte (med at se ud, som den gør). I modsætning til håbets politik som et fremsynet, reproduktivt og heteronormativt projekt må queerkritikken i Edelmans optik omfavne den negativitet, queer er sat til at symbolisere i det sociale fællesskab. Queersubjektet skal ikke trækkes ind i genkendelighedens sfære - gennem liberal identitetspolitik, der f.eks. indlemmer lgbtqi + i militæret eller i ægteskabet eller forældreskabet - det skal derimod fremsætte et radikalt nej til fremtiden.

Som flere har påpeget, sker der en glidning i denne slags antirelationel queerkritik fra en diagnose af en symbolsk reproduktion til en dom over dem, som får børn og bekymrer sig om dem. ${ }^{2}$ I hvert fald forbigås det reproduktive arbejde, bredere forstået, ikke kun som den individuelle forplantning, men som de følelser og aktiviteter og det ansvar, der er involveret i det daglige arbejde for opretholdelsen af liv. ${ }^{3}$ Edelmans "no future", som er titlen på hans bog, er på den måde en afvisning af noget, som andre mennesker ikke vil eller kan sige nej til. Desuden kan man argumentere for, at den håbefulde og udskudte fremtidshorisont selv er i krise. Den fantasi om fremtiden, som Edelman vil ødelægge med sin omfavnelse af dødsdriften, er f.eks. ifølge Franco "Bifo" Berardi allerede døet hen og erstattet af en generaliseret følelse af, at fremtiden ikke nødvendigvis bringer bedre tider med sig. Kapitalismens koblinger af fremtid med udvidelse og vækst har ikke længere rigtigt hold i den psykologiske opfattelse af fremtiden:

Fremtiden er ikke en naturlig udstrækning af sindet. Det er en modalitet af projektion og imagination, en funktion af forventning og opmærksomhed, og den modaliteter og kendetegn ændrer sig i takt med kulturelle ændringer. [Det tyvende århundrede] er gennemtrængt af en religiøs tro på fremtiden. Vi sætter ikke vores lid til fremtiden på samme måde. Selvfølgelig ved vi, at der kommer en tid efter nutiden, men vi forventer ikke, at den tid vil indfri nutidens løfter. (Berardi 24-25)

2 Se Halberstam; Power.

3 Jf. Johanna Brenner og Barbara Lasletts marxistisk-feministiske definition af social reproduktion som det, der omhandler ikke bare fødslen (af nye arbejdere) men "de aktiviteter og holdninger, adfærdsmønstre og følelser, forpligtelser og relationer, som er direkte forbundne med vedligeholdelsen af liv på daglig basis, og på tværs af generationer" (382).
Som "en modalitet af projektion og imagination" er fremtiden ligeledes radikalt udfordret af økokatastrofen, der også mere bogstaveligt skaber tvivl om, hvorvidt der kommer en menneskelig fremtid efter nutiden.

Hvis den reproduktive futurisme allerede har mistet moment som gældende psykologi, hvor affektive kvaliteter som håb, forventninger og længsler ikke længere præger menneskets sameksistens, og også som faktisk mulighed i økokatastrofens tid, er Edelmans påstand om, at fremtiden er barnets domæne og derfor ikke for queers, ${ }^{4}$ måske en utilstrækkelig analyse af barnets og reproduktionens plads i den politiske imagination. Måske skal vi lede efter en anti-anti-utopianisme ${ }^{5}$ i litteratur om økologi og slægtskab, der undgår både at bekræfte den kulturelle reproduktion og at indtage queernegativitetens anti-utopiske holdning. ${ }^{6}$

Er der en reproduktion, der ikke slår ring om fremtiden i status quos navn? Er der et barn, som snarere end at blive figur for tilbagekomsten til en håndterbar natur åbner for reproduktionens forandringspotentialer? I de følgende afsnit analyserer jeg den cirkulære energi, ikke-reproduktionen og det radikale slægtskab som en cirkulær-økologisk tænkning, der kan fungere som utopi til denne tid. Samtidig undersøger jeg, hvilke potentialer og problemer der ligger i at forbinde reproduktion og fremtidsimagination.

4 Dette er José Esteban Muñoz' beskrivelse af Edelmans position i hans modargument om, at queerness netop handler om fremtidighed og håb. Ifølge Muñoz må den antirelationelle analyse erstattes af en forståelse af "queerness som kollektivitet" (11). I denne artikel er spørgsmålet desuden, om barnet og reproduktionen kan betragtes som et sted for queer utopier i lyset af de fremtidskriser, som de samtidige politiske og økologiske kriser indebærer.

5 For Fredric Jameson er "anti-anti-utopianisme" slogan for en kritisk praksis, der bevidst forholder sig til utopiens fejlbarlighed, mens den finder den anti-utopiske holdning politisk uacceptabel (Jameson xvi). En sådan praksis er kendetegnende for et generelt skift i utopiforskningen fra at beskæftige sig med utopien som objekt til at fokusere på utopien eller utopianismen som metode. Se Levitas; Moylan \& Baccolini; Sargisson.

6 Queer-teorien har fra mange sider foreslået alternative, queer tidsligheder, der bryder med ideer om børns normative udvikling (Stockton) og med det daglige livs "krononormativitet" (Freeman). Og José Esteban Muñoz har insisteret på at forbinde queer socialitet med Ernst Blochs ideer om utopien som impuls (Muñoz). 
44 KULTUR \& KLASSE $* 129 * 2020$

KLIMA, MAGT, MODSTAND
45 IBEN ENGELHARDT ANDERSEN

UTOPISK SL ÆGTSKAB I UDRYDDELSENS TID

\section{CIRKULÆR ENERGI}

Inger Christensen minder i sit essay "Jeg tænker, altså er jeg en del af labyrinten" (1978) om at ordet révolution på fransk oprindelig betyder "en cirkelbevægelse, hvorved et bevægeligt legeme vender tilbage til sin oprindelige position." Det gælder f.eks. planeters revolution. Og det gælder mennesket, der vender tilbage til sin oprindelige position, "men forvandlet, altid forvandlet." ("Jeg tænker" 164). I Christensens fem tekster med "forsøg til en utopisk ordbog",7 der udkom i slutningen af 1970'erne, er menneskets "utopiske funktion", som hun kalder det, ligeledes koblet til en oprindelig forbindelse til den jordiske natur og det "arbejde" som omdannelsen af solens energi er for planter og dyr. Mennesket indgår ifølge Christensen i "et samarbejde med en allerede indlejret energiplan": "Vores trang til fremtid, vores forplantning og vores arbejde, hele vores utopiske funktion er vores evne til at transponere energi og formilde, måske ligefrem forskønne nedbrydningen ved vores blotte eksistens." ("energi" 140). Kapitalens vilde vækst, omsætningen af "natur plus arbejde" til penge, miskender derimod naturens vækst og realiserer den som en "kontant virkelighed" af akkumulation, merværdi og profitskabelse.

I modsætning til væksten forstået som en evigt accelereret øgning af arbejdets produktivitet, står Christensens utopi for en suspension af omsætningen og en slags tilbagevenden til menneskets forbindelse til den givne verden. Her er menneskelivet en forlængelse af naturens orden. Utopien er givet ved fødslen:

Fordi: vi fødes med en viden om verden, en hel og udelelig genkendelse, en disposition for verden. I samme øjeblik vi slår øjnene op, er verden til stede i hele sin realitet. Her er det jeg begynder at afrealisere mig selv. Med min særlige disposition (mine anlæg, som er det hvormed jeg henvender mig til andre) genkender jeg verden på én gang som den er og uophørligt finder sted, og som den ikke har fundet sted. Ikke før. Det er dette ikke-sted, som hver gang et menneske fødes, med rette kan kaldes en utopi. (Christensen, "afrealisering" 96)

7 Som en del af skriftserien Krise og Utopi, som hun var medredaktør af, skrev Inger Christensen en "utopisk ordbog" i fem dele, "standset op", som overskrifterne lyder, ved ordene "afrealisering", "arbejde", "energi", "broderskab" og "sne" (Christensen).
Som figur for selve livet minder barnet om de uafhængige, biologiske processer, vi er skabt af, og korresponderer med den ikke-menneskelige vitalitet, der "uophørligt finder sted". Her er utopiens ikke-sted (u-topi) altså ikke placeret ude på en ø, et helt andet sted. Og hvis det er en begyndelse forfra, så er der her ikke nogen fantasi om en begyndelse fra nul. Mens der er en natalisme på færde her, er det selvfølgelig ikke pronatalisme som biopolitiske opfordringer eller tvangsmæssige foranstaltninger til at reproducere en national eller racemæssig enhed. Det handler om fødslen som en synliggørelse af menneskets indlejring i den ikke-menneskelige natur og om utopien som et "arbejde" i og med det forhold.

Et eksempel på dette utopiske forhold er arbejdsforholdet mellem mor og nyfødt, hvor mælken flyder naturligt mellem bryst og mund:

Vi kommer til verden med en viden om, at noget må der gøres. Og der er ikke gået mange minutter før vi med en ufattelig energi går i gang med det første stykke arbejde, at drikke mælk af det dertil indrettede bryst. Og dette moderbryst er absolut ikke nogen automatisk virkende pumpe, men en kilde der sagligt belønner den lilles hårdtarbejdende mund ved at svare og lade mælken flyde mere rigeligt end arbejdsindsatsen egentlig tilsiger. (Christensen, "arbejde" 140)

Her giver Christensen en forståelse af det reproduktive arbejde, ikke som det ulønnede arbejde, der understøtter det lønnede og såkaldt produktive arbejde ${ }^{8}$ men som en produktion af en utopisk energi i sig selv. Over for den økonomiske tænknings vilde vækst, der dyrkes "så jeg'et effektivt kan glemme at det er en funktion af utopien" (141), må naturens vækst og menneskets indlejring være definerende for de daglige bevægelser - for digtningen såvel som for arbejdet.

Christensens tænkning resonerer i samtidig litteratur, der beskæftiger sig med menneskets uadskillelighed fra naturens processer. Men hendes tro på dette forholds orden og skønhed er alligevel udfordret af daglige billeder af, hvordan naturen er ødelagt og ødelæggende: isen smelter, luf-

8 Jf. de feministiske marxisters kritikker af de måder, hvorpå den "sociale reproduktion" af samfundet kræver ulønnet og feminiseret arbejde, skabelsen af en fiktiv opdeling mellem privat og offentligt, samt naturalisering af udbyttende sociale relationer. Se bl.a. Dalla Costa); Fortunati; Federici 
ten er forurenet, stormen kommer osv. Amerikanske Juliana Spahr er en digter, der er inspireret af og deler Christensens tanker om menneskets og kunstens indlejring i naturen, men hos hvem politiske og økologiske kriser også får helt konkret betydning. Det gælder f.eks. i That Winter the Wolf Came fra 2015, hvor netop amningen er kontamineret af kemikalier:

Some call this mothering,

this way I begin each day by holding out my hand and then all day long pass on.

Some call this caretaking,

This way all day and all night long, I hold out my hand and take engine oil additive into and then I pass on this engine oil additive to

this other thing that once was me, this not really me. (Spahr 53$)^{9}$

Mens Christensens håbefulde natursyn er svært at opretholde, er fremstillingen af den utopiske funktion som en "forskønnelse" af den naturlige vej mod døden ligeledes udfordret af feministiske perspektiver på fødsel og reproduktivt arbejde, der peger på, hvordan naturens processer kan være både ækle og ødelæggende, og hvordan den biologiske reproduktion kræver en social infrastruktur, der giver tag over hovedet, rent vand, lægehjælp osv. Den utopiske energi i det reproduktive arbejde kræver en fortsat politisering - og dermed en anerkendelse af fødslen og cirkulariteten som ambivalente utopier.

Racisme, kolonialisme, patriarkalisme og sexisme involverer alt sammen måder at opdele mennesker og deres indbyrdes forhold i naturligt og unaturligt. Mens det, der opfattes som naturligt (f.eks. den heteroseksuelle reproduktion) kan iværksættes for at udgrænse det, der opfattes som unaturligt (f.eks. queer seksualitet), kan det at forbinde kvinden eller immigranten med en tilbagestående natur være en måde at afstive den patriarkalske kultur på. Disse differentieringer har også en tidslig karakter. Julia Kristeva skriver i sit essay om "Kvindens tid" fra 1979, at den tidslighed,

9 "Nogle siger dette er moderskab,/ på den måde starter jeg hver dag med at række hånden ud og så hele dagen række videre./ Nogle siger dette er omsorgsarbejde./ På denne måde hele dagen og hele natten rækker jeg hånden ud og videregiver motorolietilsætningsstoffer til/denne anden ting, der engang var mig, denne ikke rigtigt mig."
47 IBEN ENGELHARDT ANDERSEN

UTOPISK SL ÆGTSKAB I UDRYDDELSENS TID kvinden associeres med, dels er cyklisk og forbundet med naturens rytmer (menstruation, fødsel, død), dels er den monumental og evig (reproduktionen af menneskearten). Heroverfor er mandens tid progressiv, historisk og projektdrevet. Som Elizabeth Freeman påpeger, indebærer det også en inddeling af det reproduktive arbejde som både tidløst og usynligt over for det produktive arbejde, der driver samfundet og økonomien fremad. Nogle kroppe relegeres til "en statisk eksistens uden for de historiske bevægelser" (Freeman 4). Hvis der er et - revolutionært - forhold mellem utopi og cirkularitet - hvordan undgår det så at binde kvinden (og barnet) til en natur, i hvis billede hun også bliver undertrykt?

I sin bog om suspenderede tidsligheder Enduring Time skriver Lisa Baraitser om vedligeholdelsesarbejdet (dagrenovation, børnepasning, ældrepleje osv.) som noget, der foregår i en fastkørt, ubevægelig og endeløs modus, men som også er det, der tillader hverdagslivet at fortsætte. Der er en langstrakthed forbundet med arbejdet for at holde noget ved lige, at oppebære eller understøtte noget. Det kan være vores liv eller andres liv, som vi gør daglige, lønnede som ulønnede, indsatser for at vedligeholde og understøtte. Heri er vedligeholdelsens tid forskellig fra produktionens tid eller frembruddet af det nye. Det indebærer endeløse gentagelser og er resultatløst betragtet med produktionens målestok. På den måde kræver vedligeholdelsen en affektiv tilknytning til nu'ets tid, til "den langsomme forbrænding af et øjeblik, der ligner det næste" (Baraitser 52). Samtidig har vedligeholdelsens arbejde en forbindelse til fremtiden i den forstand, at det er et arbejde for, at noget kan blive ved, at noget overhovedet kan overleve og have en fremtid. Baraitser skriver: "Mens der er en iboende konservativ og endog bagudrettet impuls inden for vedligeholdelsespraksisser, er der også tidslige funktioner ved vedligeholdelsen, der rækker fremad mod fremtiden, alt imens de forsøger at bevare tingene, som de altid har været." (53)

Dette sammenfald af det bevarende og det fremtidsrettede er måske særligt tydeligt i forældreskabet, der også adskiller sig fra andet reproduktivt arbejde, fordi den, der udfører det, ikke umiddelbart kan skiftes ud, og fordi det også indebærer at leve i tæt forbindelse med "en foranderlig anden" (Baraitser 76), der afbryder vores rytmer og stiller hensynsløse krav fra en helt igennem sårbar position. I det perspektiv er barnet ikke kun en 
48 KULTUR \& KLASSE $* 129 * 2020$

KLIMA, MAGT, MODSTAND
49 IBEN ENGELHARDT ANDERSEN

UTOPISK SLÆGTSKAB I UDRYDDELSENS TID figur for normativ udvikling eller for en natur, der bekræfter sig selv. Barnet kommer også med et spørgsmål om ikke-reproduktion, om hvad man ikke kan eller vil fortsætte med.

\section{IKKE-REPRODUKTION}

Planeten Jorden har, i dens nuværende tilstand, ikke brug for at få tilføjet flere personer. I hvert fald ikke flere af "os", der endnu ikke har fundet ud af at leve og dø uden at overbelaste planeten og undergrave både menneskelige og ikke-menneskelige livsformer. Men at propagere for et fald i befolkningstal er ikke desto mindre koblet til historier af systemisk kolonialisme, hvid nationalisme og folkemord. Fra den Malthusianske administrative opfattelse af befolkning som et spørgsmål om kvantitet til det 20. århundredes racehygiejniske projekter og videre ind i nutiden manifesterer racisme, misogyni og nationalisme sig i form af stratificeret reproduktion. ${ }^{10}$

Donna Haraway mener i Staying with the Trouble fra 2016, at den eneste mulighed for økologisk retfærdighed er, at vi bliver færre mennesker på jorden. Frygten for at genoptage racistiske, nationalistiske og imperialistiske tankegange kan ikke stå i vejen for en antikolonialistisk, feministisk tilgang til "den Store Acceleration" (6) - en befolkningstilvækst, der hos Haraway formuleres som et akut problem. Hun skriver: "en stigning på 9 milliarder mennesker over 150 år til et niveau på 11 milliarder inden 2100, hvis vi er heldige, er ikke kun et tal; og det kan ikke bortforklares ved at bebrejde kapitalismen [...]" (6). De menneskeskabte belastninger af planeten kan ikke omdirigeres ved hjælp af kritikker af det bestående, men kræver nye

10 For eksempel dyrker det radikale højre en konspirationsteori om, at hvide befolkninger gradvist bliver udskiftet (er ordet) af ikke-hvide befolkninger fra Nordafrika og Mellemøsten gennem masseimmigration og demografisk vækst. Terroristerne fra Christchurch og El Paso er to eksempler på en fornyet såkaldt økofascisme, der ikke benægter, at menneskelige aktiviteter er årsag til klimaforandringer, men som sammentænker immigrationskrise og økokrise: Der er for mange mennesker på kloden; vores liv kan kun blive bæredygtige, hvis vi skiller os af med andre liv, immigranternes og muslimernes, lyder deres manifester. Se bl.a. https://theweek. com/articles/857100 (Web, 25. marts 2020); https://www.motherjones.com/environment/2019/08/the-el-paso-manifesto-where-racism-and-eco-facism-meet/ (Web, 25. marts 2020). vidensformer og, helt centralt, nye reproduktive praksisser. Vi må skabe slægt, ikke babyer ("make kin, not babies"), skriver hun, for at dæmme op for den sjette masseudryddelse.

Med dette antinatalistiske slogan mener Haraway, at slægtskab må blive lateralt snarere end biologisk og genealogisk; det må indbefatte familiedannelse, der ikke grundes i fødsel eller af artsfællesskab. Forældreskabet skal inkludere flere og andet end et heteroseksuelt par; familier må udvides kvalitativt snarere end kvantitativt. Queer relationer og samhørighed på tværs af arter vil føre til højnet økologisk retfærdighed og mere robuste økosystemer for mennesker såvel som ikke-mennesker (159). Desuden vil nye fortællinger være del af og resultat af denne slægtskabsudvidende praksis. Haraways argument er, at radikale ændringer i vores forplantningspraksisser har potentiale til at omdirigere den klimamæssige katastrofekurs og altså historiens gang, og at den litterære imagination har potentiale til at "bevæge" os i nye retninger. ${ }^{11}$ Hun skriver sig ind i en tradition for feministisk utopisk litteratur, der skildrer andre måder at organisere sig familiemæssigt på, ${ }^{12}$ og slutter Staying with the Trouble med en utopisk fortælling, The Camille Stories. Her fremspekuleres en baby, Camille, der over fem generationer skal lære "at reducere presset fra mennesker på jorden radikalt" (136). Haraway fortæller historien fra år 2425, hvor den femte Camille netop er død. Befolkningsreduktion er opnået ad frivillighedens vej:

11 Haraway skriver: "Kin making is making persons, not necessarily as individuals or as humans. I was moved in college by Shakespeare's punning between kin and kind-the kindest were not necessarily kin as family; making kin and making kind (as category, care, relatives without ties by birth, lateral relatives, lots of other echoes) stretch the imagination and can change the story." (103). Dansk oversættelse: "Slægtskabelse er skabelsen af personer, ikke nødvendigvis som individer eller som mennesker. Jeg blev rørt i college af Shakespeares ordspil på slægt og slags - de mest elskværdige var ikke nødvendigvis slægt som i familie, at skabe slags og slægtninge (som kategori, omsorg, pårørende uden fødselsbånd, laterale slægtninge, masser af andre ekkoer) udvider forestillingsevnen og kan ændre historien."

12 Se f.eks. Mary E. Bradley Lanes Mizora fra 1890, Charlotte Perkins Gilmans Herland fra 1915, Marge Piercys Woman on The Edge of Time fra 1976, Ursula Le Guins The Disposessed fra 1974 eller The Left Hand of Darkness fra 1969. 
50 KULTUR \& KLASSE $* 129 * 2020$
51 IBEN ENGELHARDT ANDERSEN

UTOPISK SLÆGTSKAB I UDRYDDELSENS TID
Over Camille-slægtens fem generationer, faldt [...] det samlede antal mennesker på jorden fra højdepunktet på 10 milliarder i 2100 til et stabilt niveau på 3 milliarder i 2400. Hvis kompostsamfundene ikke havde vist sig fra deres tidligste år at være så vellykkede og så smitsomme blandt andre mennesker og folk, ville jordens befolkning have nået mere end 11 milliarder inden 2100. Det ånderum, som denne forskel på en milliard mennesker tilvejebragte, åbnede muligheder for vedvarenhed [ongoingness] for mange truede måder at leve og dø på for både mennesker og ikke-menneskelige væsener. (144)

I Haraways utopi vælges børn fra, mens nære relationer udvides og understøttes i Kompost-samfundet, som det hedder. Det indebærer ingen fantasi om at starte forfra et andet (ubeboet) sted eller i fremtiden. Der skal ikke begyndes fra ingenting, der er derimod en ambition om at lære at leve "i ruinerne" (138) af den verden, vi har skabt. I Camille-utopien er der genkomst, genbrug og gentagelser, og en understregning af, hvordan masseudryddelsen ikke er en metafor, men en "igangværende katastrofe" ("Making Kin" 78). Sym-poeisis er derudover Haraways betegnelse for den reproduktion, kompostsamfundet vil basere sig på. Nye børn vil blive parret med en "dyre-symbiont", som udvælges blandt truede dyrearter, og fra hvem babyerne vil få "et par gener og et par mikroorganismer" (Staying 141). Denne biologiske sammenkædning sker sådan, at mennesket får højnet sin følsomhed og sit ansvar over for verden, som den opleves af dyret (ibid.). Sym-poetisk slægtskab og flerartet fællesskab skal og vil ifølge Haraways utopi føre til, at der bliver født færre børn og dermed til en større grad af økologisk retfærdighed.

Der har været fremført flere kritikker af dette spekulative projekt. Sophie Lewis kritiserer f.eks. Haraway for at have forladt den marxistisk-feministiske analyse til fordel for ønsket om artsmæssig pluralisme; det, som hos Haraway bl.a. hedder flerartet retfærdighed ["multispecies justice"] og at skabe sær-slægt ["making oddkin"] (Lewis). Mens det at skabe omsorgsrelationer, der rækker ud over de biogenetiske familieforhold, har været både nødvendigt og mulighedsfyldt for alenemødre, for queer fællesskaber, prekære arbejdere, immigranter osv., er Haraways utopi meget lidt optaget af forudsætninger og mulige strategier for at opnå reproduktiv retfærdighed ad politisk og økonomisk vej. På den måde er Camille-fortællingerne en utopi uden revolution, skriver Lewis: "den revolutionære gnist i Haraways 'mere-end-menneskelighed' er tilsyneladende blevet slukket undervejs og erstattet af et apolitisk begreb om tvær-artsligt Gemeinschaft".
Klimakrisens årsager og effekter er differentielt distribueret, og når vi taler om uomgængelige katastrofer og mulige reaktioner på disse, må vi også tale om, hos hvem og hvor de findes. Hvis fremtid taler vi om, når vi siger, at den er mere usikker end nogensinde? Og hvem er det "vi", der skal skabe slægt, ikke babyer, altså omlægge reproduktionsformen? Økokatastrofen må, som Michelle Murphy formulerer det, føre til diskussioner af distribueret futuritet, ikke differentieret fertilitet: Reproduktiv retfærdighed skal ikke handle om fødselsrater, men om, hvilke slægtskaber og livspraksisser der understøttes, og hvilke der ikke gives en fremtid.

Haraway kobler forestillinger om udvidet slægtsskabsdannelse med antinatalismen på måder, der ikke helt lykkes at komme uden om populationsdiskursens betændte politiske historie. Sophie Jones formulerer en beskrivelse af ikke-reproduktive praksisser, der indbefatter Haraways laterale slægtskab, altså spørgsmålet om, hvordan man kan skabe bedre social og omsorgsmæssig infrastruktur uden for kernefamiliens rammer. Samtidig er hun interesseret i, hvordan "barnet" eller det reproduktive arbejde også kan være i opposition til den sociale reproduktion:

en feministisk (ikke-)reproduktionspolitik anerkender alle de måder, hvorpå bør neopdragelsen kan indebære en modstand mod at reproducere den gældende orden. Lad os altså tænke reproduktion som ikke-reproduktion: hvordan det at få børn blotlægger det absurde og irrationelle ved vores arbejdsformer [ways of working], at bringe nye mennesker til verden, der måske vil ændre på tingene. Lad os samtidig tænke ikke-reproduktion som reproduktion: som relationer af omsorg og slægtskab, der trives uden for og i opsætsighed mod kernefamilien. (Jones et al.)

Snarere end ikke-reproduktionen som nægtelse hos Edelman (nej til barnet) eller som subtraktion hos Haraway (færre børn) kan Jones' formulering om det revolutionære potentiale i børneopdragelse føre til analyser af, hvordan specifikke reproduktive praksisser trives eller umuliggøres, analyser, som også finder utopisk energi i ikke-vestlige eller ikke-hvide måder at skabe slægt og familieliv på. ${ }^{13}$

13 Angela Davis beskriver f.eks., hvordan slavegjorte kvinder ikke ansås som juridiske mødre for deres børn, der for de hvide slaveejere var potentiel arbejdskraft. Samtidig forventedes disse kvinder at drage omsorg for og i nogle tilfælde amme ejernes børn. "Den reproduktive rolle, som blev påtvunget afrikanske kvindelige 
52 KULTUR \& KLASSE $* 129 * 2020$

KLIMA, MAGT, MODSTAND
53 IBEN ENGELHARDT ANDERSEN

UTOPISK SLÆGTSKAB I UDRYDDELSENS TID

\section{RADIKALT SLÆGTSKAB}

Hiromi Itos Vildgræs ved flodlejet er et langdigt fortalt af en 11-årig pige, som med sin mor og lillebror er i konstant bevægelse. De rejser med forskellige transportmidler og befinder sig i forskellige lufthavne og immigrationshaller med deres "dårlige pas" og i kolde gange, hvor immigranter desperate og energiforladte venter overalt. "Lige meget hvor mange gange vi ankom, så var det stadig ikke slut" (9), siger barnet. Men en dag i lufthavnen tager en mand ivrigt imod dem, han stikker tungen ind i morens mund og gramser på hendes krop, hvorpå hun og børnene flytter hjem til ham i "ødemarken". Her bliver han snart til "far". Pigen registrerer halvnaivt de voksnes forhold; sex lyder f.eks. i barnets ører "som lyden af en klud, der bliver sjasket rundt i en spand vand" (10), og moren begynder at tale og bevæge sig på fremmede måder. Nu skal de ikke længere tale japansk, men tilpasse sig omgivelserne og det engelske sprog.

En ny baby kommer til. Moren planter en vildvin, som vokser alt for vildt, og hvide skjoldlus dækker alting: hus, planter og kroppe. Ørkenvinden blæser, og "den store, skæggede far" (14) bliver syg og dør. Men han bliver ikke begravet, for måske kommer han tilbage til næste år, siger moren. Han ligger fremme som et levende lig, der siger: "Damn it, damn it", en helt latterlig patriark: "Damn it (jeg har ret)/ Damn it (jeg er den eneste, der har ret)" (18).

Moren giver sig til at udrydde bladlusene, der har bredt sig overalt. I sit beskæringstrip klipper hun faderligets penis af: "Min lillebror spurgte, er den død?/ Min mor sagde, lad den være, og den vil vokse ud igen" (21). Og moren beslutter sig for, at de skal tage tilbage til flodlejet. Her vender de tilbage til et hus, som er viklet ind i sivplanter og vildgræs og til en ny far, der er et lig blandt mange. Døden er en vital størrelse her. Planter som mennesker dør og formerer sig efter denne formel:

slaver, havde intet at gøre med moderskabet som subjektivt projekt" (213). Kampen for reproduktiv retfærdighed har ikke bare haft som mål at sikre sorte kvinder de samme rettigheder, som hvide kvinder har opnået i forhold til deres børn, men har også - i dens mere radikale projekter - handlet om at gøre op med ejerskabstanken i det hele taget.

\author{
At leve \\ Er mere almindeligt \\ End at dø for planter \\ De kommer tilbage \\ De fortsætter \\ De dør ikke \\ De rejser sig fra de døde \\ De bliver levende igen \\ De vokser frem igen, lige meget, hvad de møder \\ De føder et utal af børn" (86)
}

Vildgræsset, der nægter at lade sig slå ned, er eksempel på den ukontrollable vækst, som naturen også er - med og uden menneskets indblanding. Samtidig er planterne billede på de forviklinger, som opstår, når mennesker migrerer. Planternes - og migrationens - flertydige vildskab står over for et forsøg på at ordne den vilde vækst: "(Lad dig bære fra dit hjemland til fremmed jord, blive vildtvoksende, naturaliseret og/ forplante dig.)/ Paspalum urvillei/ Verbena brasiliensis/ Conyza sumatrensis" (83). Planterne angives ved deres latinske navne, som gentages, sammenlignes og rubriceres - og mimer således en klassificeringstrang, der giver alle skabninger en fast plads i den naturlige økonomi.

Samtidig er plantenavnene også en måde at forholde sig til naturen som sprog, og sproget som natur, ligesom hos Inger Christensen, for hvem digtningen er en forlængelse af "det biologiske rum" ("afrealisering" 96). Men hos Ito forstyrres denne ordning af den ækle natur, der ingen grænser kender, som overgriber og trænger ind i menneskekroppene. Derudover er sproget også hos Ito en politisk kampplads, hvor det japanske modersprog må glemmes, for at man kan leve i det nye sprog.

Er børnene forsømte i dette vildgræsunivers? Ja. De voksne masturberer foran dem, dør foran dem og overlader dem oftest til sig selv. Og som immigrantbørn afhænger deres fremtidsmuligheder af grænsekontrollens afgørelser. Men alligevel er morens svigt ikke helt til at bestemme; hun kærtegner børnene, ammer dem og tager dem med sig, når hun må afsted. F.eks. vil hun, da lillebroren får et voldsomt udslæt, køre dem alle til en helbredende kilde. Men den kan de alligevel ikke finde: "Intet kureret, Intet ordnet,/ Intet fundet,/Ingenting" (60). 
54 KULTUR \& KLASSE $* 129 * 2020$

Derimod kommer naturen på andre måder til at stå for en slags kur eller en omsorg, som er radikal. Politiet kommer og finder farens lig og tager moren med sig, mens børnene forsvarer sig med hunde, ildspåsættelse og gevær. De vil ikke med, de ønsker at "blive en del af flodlejet" (73). Det er også her, der pludselig er fire børn i digtsamlingens univers. Aleksa introduceres: "Vi ønskede at blive til flodlejet/Med 'os' mener jeg Aleksa og mig og min lillebror og lillesøster." (31). Den dem/os-logik, som de nationalstatslige grænser står for, både mimes og sprænges her, hvor "os" inkluderer en fjerde, ubestemmelig skabning. Hun kommer ingen steder fra og kan læses som nogle kræfter i jegfortælleren, en slags pubertær udspaltning:

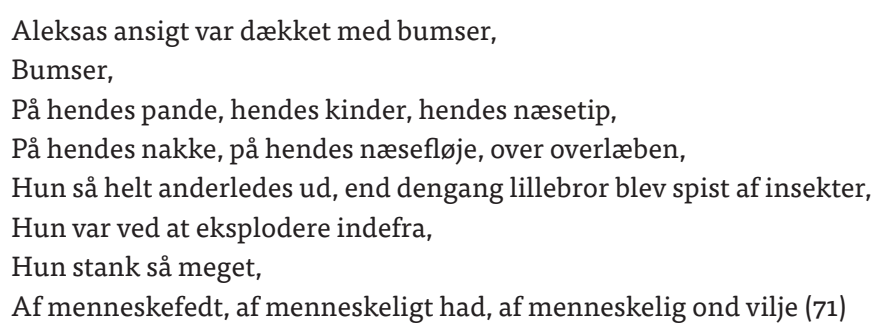

Men Aleksa er også en anden person og som sådan en allieret. Hun er en beskytter, der hjælper børnene i kampen mod politiet. Og så er hun vildgræs. Titeldigtet hedder "Kawara Arekusa, eller vildgræs ved flodlejet", og her, hvor Aleksa jager politiet væk, knyttes hendes navn til græsset: "Aleksa (Arekusa) skreg, kom nu ind i huset alle sammen, så slap hun hundene løs" (71). ${ }^{14}$ Det pubertære oprør er ikke kun udtryk for desillusion, men en transformation, der samler et nyt, energisk modstandsfællesskab: "Der blev stille et øjeblik, alle holdt op med at bevæge sig,/ Så skreg alle på en gang" (71).

Med sin gennemløbende forhandling af grænserne for, hvad der konstituerer et "vi", og med sin inklusion af flerartede eksistenser i bogens komplekse omsorgsrelationer forbinder Vildgræs ved flodlejet økologi og social infrastruktur. I den forbindelse kan utopien ikke tilbyde en entydig vej fremad, men peger snarere i skikkelse af en pubertær teenager, der bli-

14 Oversætteren noterer, at Aleksa på japansk skrives som Arekusa, altså som vildgræs, og at det lydlige sammenfald i titlen også peger frem til, hvordan hun gradvist i digtsamlingen går i ét med flodlejet.
55 IBEN ENGELHARDT ANDERSEN

UTOPISK SL ÆGTSKAB I UDRYDDELSENS TID

ver til en plante, på en queer vækst. Her er de grænseløse forbindelser en række overskridelser af passets lov, ligesom det radikale slægtskab bliver et utopisk alternativ til familiens destruktive ramme.

\section{KONKLUSION}

Den traditionelle utopis tro på en radikalt ny samfundsindretning som noget, man kan beslutte sig for, og som kan opstå ud af intet, udfordres af økologiens påmindelse om, at mennesker er indlejrede i naturlige miljøer og forbundne og afhængige af hinanden. Det er kun de superrige, der kan starte forfra og bygge rumraketter eller stormsikre ø-forter. Klimakatastrofen er en reel, igangværende trussel mod eksisterende og fremtidige fællesskaber. Som genre er dystopien muligvis tidssvarende i sin skildring af et affektivt landskab af frygt og håbløshed og med sine ideer om, at tingene kan blive meget værre. Antropocæn er en biosfærisk dystopi, som forfatteren Kim Stanley Robinson skriver. Som sådan er den en nødsituation, der tvinger os til at forestille os, hvordan tingene kan blive bedre.

Den utopiske tanke er nødvendig, men altså kun mulig, hvis den forbinder sig til en eksisterende økologi. Samtidig er utopien en måde at komplicere forståelsen af det cykliske som noget statisk-reaktionært. Utopien kan være en måde at finde en vej uden om reproduktionen forstået som en bekræftelse og fortsættelse af tingenes tilstand, men uden at man forlader en økologisk nødvendig opmærksomhed på forbundethed, vedligeholdelse, og vedbliven, der kendetegner det reproduktive arbejde. I de tre perspektiver, jeg har præsenteret ovenfor, er fødsel, amning, slægtskab og opvækst steder, hvor det økologiske, det individuelle og det politiske er viklet ind i hinanden, og hvor reproduktionens sfære også bliver et sted for mulig modstand: naturens vækst over for kapitalens vækstprincipper hos Inger Christensen, Donna Haraways flerartede slægtskab, Hiromi Itos queer vækst.

IBEN ENGELHARDT ANDERSEN, postdoc i projektet Utopia Without Future på Institut for Kunst- og Kulturvidenskaber, Københavns Universitet. Har senest publiceret artikler i Textual Practice og Vagant. 


\section{UTOPIAN KINSHIP IN THE ERA OF EXTINCTION}

This article examines how utopian and ecological thinking connect in light of the ongoing eco-catastrophe. While the dystopic genre might be timely as it depicts an affective landscape of fear and hopelessness and communicates ideas about how things can get much worse, the article suggests that utopian imagination is necessary but only possible if it connects with an existing ecology. It presents three utopian perspectives on the entanglements of reproduction and ecological sustainability -Inger Christensen's circular energy, Donna Haraway's non-reproduction, and Hiromi Ito's radical kinship - that link utopian imagination, feminist temporalities and questions of sustainability. The focus on birth, childhood and kinship illustrates how biology, social practices and phantasms affect one another and how ecology brings these levels together, while connecting intimate questions and global problematics. The analyzed texts articulate instances of "utopian kinship" that sidestep the mechanisms of reproductive futurism or reproduction understood as a confirmation and continuation of the way things are. As such, they point to the reproductive sphere as a place for resistance: queer growth, multispecies kinship, nature's work against capitalism's principles of development.

\section{KEYWORDS}

EN: utopianism, kinship, ecology and literature, poetry, reproductive work DA: utopi, slægtskab, økologi og litteratur, poesi, reproduktivt arbejde

\section{LITTERATUR}

Baraitser, Lisa. Enduring Time. London: Bloomsbury, 2017.

Berardi, Franco "Bifo". After the Future. Edinburgh: AK Press, 2011.

Black, Bill. "The El Paso schooter's manifesto contains a dangerous message about climate Change". The Week, 6. august 2019, https://theweek.com/articles/857100.

Brenner, Johanna og Barbara Laslett. "Gender and Social Reproduction: Historical Perspectives". Annual Review of Sociology, nr.15, 1989, s. 381-404.

Christensen, Inger. "Jeg tænker, altså er jeg en del af labyrinten". Essays, København: Gyldendal, 2019, s. 159-168.

Christensen, Inger. "Forsøg til en utopisk ordbog standset op ved det første ord: afrea-
57 IBEN ENGELHARDT ANDERSEN

UTOPISK SL \&GTSKAB I UDRYDDELSENS TID lisering". Krise og Utopi: Vækst, redigeret af Inger Christensen, Niels L. Meyer og OleThyssen, København: Gyldendal, 1979, s. 92-96.

Christensen, Inger. "Forsøg til en utopisk ordbog standset op ved det andet ord: arbejde". Krise og Utopi: Arbejde, Arbejdsløshed, redigeret af Inger L. Christensen, Niels Meyer og Ole Thyssen, København: Gyldendal, 1979, s. 139-144.

Christensen, Inger. "Forsøg til en utopisk ordbog standset op ved det tredje ord: energi". Krise og Utopi: Energi, redigeret af Inger L. Christensen, Niels Meyer og Ole Thyssen, København: Gyldendal, 1979, s. 139-141.

Christensen, Inger. "Forsøg til en utopisk ordbog standset op ved det fjerde ord: broderskab". Krise og Utopi: Demokrati, redigeret af Inger Christensen, Niels L. Meyer og OleThyssen, København: Gyldendal, 1980, s. 156-159.

Christensen, Inger, Niels L. Meyer og Ole Thyssen."Sne". Krise og Utopi: Krig eller fred, redigeret af Inger Christensen, Niels L. Meyer og Ole Thyssen,. København: Gyldendal, 1981.

Dalla Costa, Mariarosa og Selma James. The Power of Women and the Subversion of the Community. Bristol: The Falling Wall Press, 1973.

Davis, Angela. "Surrogates and Outcast Mothers". The Angela Y. Davis Reader, redigeret af Joy James, Malden, MA: Wiley-Blackwell, 1998, s. 210-221.

Edelman, Lee. No Future - Queer Theory and the Death Drive. Durham, NC: Duke University Press, 2004

Federici, Silvia. Wages for Housework: The New York Committee 1972-1977: History, Theory, Documents. Brooklyn, NY: Autonomedia, 2017.

Freeman, Elizabeth. Time Binds - Queer Temporalities, Queer Histories. Durham, NC: Duke University Press, 2010.

Fortunati, Leopolda. The Arcane of Reproduction - Housework, Prostitution, Labor and Capital. Brooklyn, NY: Autonomedia, 1995.

Halberstam, Judith. "The Anti-Social Turn in Queer Studies", Graduate Journal of Social Science, bd. 5, nr. 2, 2008, s. 140-156.

Haraway, Donna Jeanne. Staying with the Trouble, Making Kin in the Chthulucene. Durham, NC: Duke University Press, 2016.

Haraway, Donna Jeanne. "Making Kin in the Chthulucene: Reproducing Multispecies Justice". Making Kin, Not Population, redigeret af Adele Clark og Donna Haraway, Chicago, ILL: Prickly Paradigm Press, 2018.

Ito, Hiromi. Vildgræs ved flodlejet. København: Arena, 2018.

Jameson, Fredric. Archeologies of the Future - The Desire Called Utopia and Other Science Fictions. London \& New York: Verso, 2005.

Jones, Sophie, Harriet Cooperog Fran Bigman, forfattere og gæsteredaktører. Studies in the Maternal, bd. 6, nr. 1, 2014, s. 1. DOI: http://doi.org/10.16995/sim.1 (Web, 25. marts 2020).

Kaufman, Alexander C. "The El Paso Manifesto: Where Racism and Eco-Fascism Meet". Mother Jones, 5. august 2019, https://www.motherjones.com/environment/2019/o8/ the-el-paso-manifesto-where-racism-and-eco-facism-meet/

Kristeva, Julia, et al. "Women's Time". Signs, bd. 7, nr. 1, 1981, s. 13-35. 
Levitas, Ruth. Utopia as Method. London: Palgrave Macmillian, 2013.

Lewis, Sophie. "Cthulhu plays no role for me". Viewpoint Magazine, 7. maj 2017, https:// www.viewpointmag.com/2017/05/08/cthulhu-plays-no-role-for-me/

Moylan, Tom og Raffaella Baccolini, redaktører. Utopia. Method. Vision. Bern: Peter Lang, 2007.

Murphy, Michelle. "Against Population, Towards Alterlife". Making Kin, Not Population, redigeret af Adele Clark og Donna Haraway. Chicago, ILL: Prickly Paradigm Press, 2018, s. 101-124.

Muñoz, José Esteban. Cruising Utopia: The Then and There of Queer Futurity. Durham, NC: Duke University Press, 2009.

Power, Nina. "Brief Notes towards a Non-Nihilistic Theory of Non-Reproduction". Studies in the Maternal, bd. 6, nr. 1, 2014, s. 1-3. DOI: http://doi.org/10.16995/sim.2 (Web, 25. marts 2020).

Robinson, Kim Stanley. "Dystopias Now". Commune Magasine, 11. februar 2018, https:// communemag.com/dystopias-now/

Sargisson, Lucy. Utopianism in the $21^{\text {st }}$ Century. London: Palgrave Macmillian, 2012.

Spahr, Juliana. That Winter the Wolf Came. Berkeley, CA: Commune Editions, 2015.

Stockton, Kathryn Bond. The Queer Child - Growing Sideways in the 21th Century. Durham, NC: Duke University Press, 2009. 